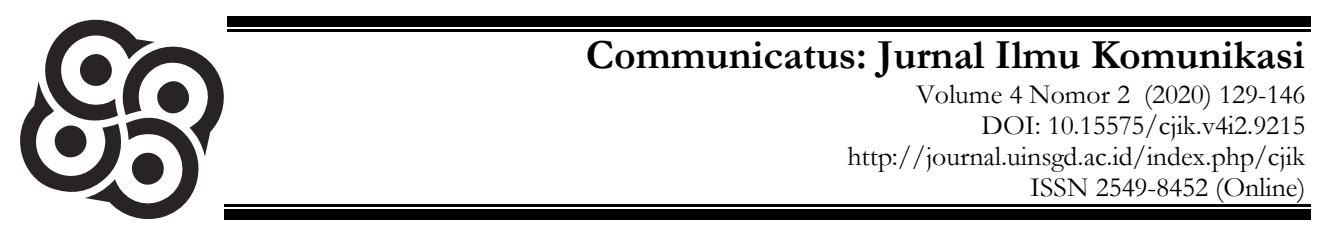

\title{
Perilaku Informasi Mahasiswa dan Hoaks di Media Sosial
}

\author{
Febri Nurrahmi ${ }^{1 *} \&$ Hamdani M. Syam ${ }^{2}$ \\ 12 Universitas Syiah Kuala \\ * email: febri.nurrabmi@unsyiah.ac.id
}

\begin{abstract}
The rise of hoaxes circulating on social media makes university students as active social media users vulnerable to distribute hoaxes. The study aims to examine information behaviors of university students in combating hoaxes on social media. It deployed the model of information behavior by Wilson (1996). Using a qualitative approach, data collection was conducted through focus groups discussions with 14 students of Syiah Kuala University. The results showed that university students possessed critical attitudes by not easily trusting information on social media. However, most of them did not have sufficient will and abilities to verify information they received from social media. The low level of self-efficacy encouraged students to be reluctant and difficult to conduct information searches for verification. Information dissemination behavior without verification was also found in this study. The results of this study also indicated that passive attention and search were the most dominant information behaviors among students. Wilson's information behavior study model is relevant and important for developing social media literacy models among college students to ward off hoaxes.
\end{abstract}

Keywords : hoax; social media; information behavior.

\begin{abstract}
ABSTRAK
Maraknya hoaks yang beredar di media sosial menjadikan mahasiswa sebagai pengguna media sosial aktif, rentan menjadi penyebar hoaks. Penelitian ini bertujuan untuk melihat perilaku informasi mahasiswa dalam menghadapi hoaks di media sosial. Penelitian menggunakan model perilaku informasi oleh Wilson (1996). Dengan menggunakan pendekatan kualitatif, pengumpulan data dilakukan dengan focus groups discussion terhadap 14 orang mahasiswa Universitas Syiah Kuala. Hasil penelitian menunjukkan bahwa mahasiswa memiliki sikap kritis dengan tidak mudah mempercayai informasi yang diterimanya dari media sosial. Namun, mayoritas mahasiswa tidak memiliki kemauan dan kemampuan verifikasi informasi memadai. Self-efficacy yang rendah menyebabkan mahasiswa enggan dan sulit melakukan pencarian informasi untuk verifikasi. Perilaku penyebaran informasi tanpa verifikasi juga masih ditemukan. Hasil studi ini juga mengindikasikan bahwa perilaku perhatian dan pencarian pasif adalah perilaku yang paling dominan di kalangan mahasiswa. Model studi perilaku informasi dari Wilson ini relevan dan penting untuk mengembangkan model literasi media sosial di kalangan mahasiswa untuk menangkal hoaks.
\end{abstract}

Kata kunci : hoaks; media sosial; perilaku informasi.

Diterima: Juli 2020. Disetujui: Oktober 2020. Dipublikasikan: Desember 2020 


\section{PENDAHULUAN}

Media sosial adalah situs internet yang paling popular di kalangan pengguna internet di Indonesia. Youtube, Facebook, WhatsApp dan Instagram sebagai situs jejaring sosial dengan jumlah pengguna aktif terbesar di Indonesia (Statista, 2020b). Namun maraknya penggunaan media sosial berimplikasi pada penyebaran berita palsu (fake news) atau hoaks di media sosial. Menurut KBBI, hoaks berarti berita bohong (KBBI Daring, 2019). Lebih spesifik, Lazer et al. (2018) menyatakan bahwa hoaks atau berita bohong mengandung informasi bohong yang menyerupai konten berita. Berdasarkan riset yang dilakukan oleh Masyarakat Telematika Indonesia (Mastel) pada tahun 2017, media sosial (Facebook, Twitter, Instagram, dan Path) merupakan saluran yang paling banyak digunakan dalam menyebarkan hoaks yakni sebesar 92,40\% (Mastel, 2017)

Penyebaran hoaks di media sosial sudah sangat memprihatinkan. Kementerian Komunikasi dan Informatika (Kominfo) menemukan 771 konten hoaks selama periode pemilu 2019, sejak Agustus 2018 hingga Februari 2019 (Kominfo, 2019). Lebih lanjut, ditemukan bahwa sebagai besar konten hoaks tersebut yaitu sejumlah 181 konten hoaks terkait isu politik baik yang sifatnya menyerang pasangan capres dan cawapres maupun partai politik peserta pemilu 2019 (Kominfo, 2019). Hasil studi Aminah and Sari (2019) memperlihatkan bahwa hoaks yang beredar di Facebook dapat memprovokasi, menimbulkan kebencian dan mengubah pilihan politik pemilih pemula. Hoaks sangat berbahaya karena bisa menimbulkan keresahan, menyebarkan kebencian, mengancam persatuan dan kesatuan bangsa serta merusak stabilitas nasional. Hal ini yang mendorong pemerintah membentuk Badan Siber Nasional dan bekerja sama dengan Dewan Pers dan Facebook di samping pemblokiran situs untuk menangkal hoaks (Siswoko, 2017).

Dilihat dari demografi, pengguna media sosial terbesar adalah rentang usia 19-34 tahun (APJII, 2017; Statista, 2020a). Mahasiswa strata 1 (S1) masuk dalam kategori usia tersebut. Sebagai pengguna aktif, mahasiswa turut berperan serta sebagai produsen, konsumen sekaligus distributor konten di media sosial. Hal ini terkait dengan karakteristik konten oleh pengguna (user generated content) yang dimiliki oleh media sosial (Nasrullah, 2015). Karakteristik ini juga didukung dengan adanya fitur share di media sosial yang memudahkan penyebaran konten (Nasrullah, 2015). Dalam konteks ini, mahasiswa sebagai pengguna aktif media sosial rentan menjadi penyebar konten hoaks. Oleh karena itu, studi ini dilakukan pada mahasiswa S1.

Penelitian ini menggunakan model perilaku informasi dari Wilson tahun 1996. Di antara model pencarian informasi, kelebihan model Wilson adalah konsep yang dinamakannya "sesemesta pengetahuan" yang artinya model ini berlaku sebagai kerangka pemikiran untuk mengembangkan dan menguji 
kombinasi baru konstruk dan teori perilaku informasi dengan berbagai macam kelompok pengguna dari berbagai bagian dunia (Al-Suqri \& Al-Aufi, 2015). Model Wilson tahun 1996 adalah revisi model yang mengintegrasikan penelitian dari berbagai bidang di luar ilmu informasi, termasuk studi pengambilan keputusan, psikologi, inovasi, komunikasi kesehatan dan penelitian konsumen (Wilson, 1999, 2007). Model ini merupakan revisi dari dua model yang dikemukakannya pada tahun 1981 (Garg, 2016; Wilson, 1999). Pada tahun 1999, Wilson kembali mengemukakan revisi terbaru dari model perilaku informasi. Model tahun 1999 merupakan model pemecahan masalah tujuan dengan asumsi bahwa jenis informasi tertentu membantu menyelesaikan suatu masalah (Al-Suqri \& Al-Aufi, 2015). Sedangkan fokus dari penelitian ini adalah melihat bagaimana perilaku informasi mahasiswa sebagai pengguna media sosial dalam memverifikasi informasi yang diterima hingga akhirnya meneruskan informasi tersebut. Dengan mempertimbangkan tujuan penelitian ini, model tahun 1996 dianggap lebih sesuai dengan kajian dalam studi ini.

Menurut Wilson (1999), perilaku informasi adalah kegiatan di mana seseorang dapat terlibat dalam mengidentifikasi kebutuhan informasinya sendiri, mencari informasi tersebut dalam berbagai cara, dan menggunakan atau mentransfer informasi tersebut. Lebih lanjut, Wilson (2000) mendefinisikan perilaku informasi sebagai keseluruhan perilaku manusia dalam kaitannya dengan sumber dan saluran informasi termasuk pencarian informasi baik secara aktif maupun pasif serta penggunaan informasi.

Pada model 1996, Wilson memperkenalkan tiga konstruk, yaitu konteks kebutuhan informasi (context of information needs), pencarian informasi (information seeking), pemrosesan dan penggunaan informasi (information processing and use) (Wilson, 1999, 2000, 2007). Wilson (2007) mengatakan bahwa kebutuhan adalah kondisi mental yang sangat subjektif dan berlangsung dalam pikiran seseorang. Oleh karena itu kebutuhan dapat diklasifikasikan berdasarkan motif. Wilson mengemukakan tiga kebutuhan informasi utama yaitu psikologis, kognitif, dan afektif (Wilson, 1999, 2000, 2007). Wilson mendefinisikan konstruk pertamanya dengan konteks kebutuhan informasi karena berbagai jenis kebutuhan pengguna dianggap sebagai bagian dari konteks di mana kebutuhan akan informasi disadari dan dikejar (Al-Suqri \& Al-Aufi, 2015).

Lebih lanjut, model ini mengatakan bahwa kebutuhan informasi tidak serta merta mendorong aktivitas pencarian informasi (Faturrahman, 2016). Terdapat dua variabel moderator yang disebut activating mechanism dan intervening variables dan bertindak sebagai barriers dalam pencarian informasi (Wilson, 1999). Pertama, model ini mendefinisikan kecemasan dan stres karena kurangnya informasi, insentif positif dan negatif bagi pencari informasi, serta self-efficacy pencari informasi sebagai activating mechanism yang memicu orang untuk melakukan 
pencarian informasi (Al-Suqri \& Al-Aufi, 2015). Kedua, penggunaan istilah intervening variables yang meliputi psikologis, demografis, role-related interpersonal, lingkungan, dan karakteristik sumber informasi merupakan faktor yang menentukan tingkat keberhasilan dalam memenuhi kebutuhan informasi karena dampak dari faktor-faktor tersebut tidak hanya untuk mencegah atau menghambat, namun juga mendukung perilaku pencarian informasi (Meilinda, Prabujaya, \& Murti, 2018; Wilson, 1999).

Saat kebutuhan akan informasi dipicu dan didukung oleh activating mechanism dan intervening variables yang memadai, maka perilaku pencarian informasi akan terwujud. Terdapat empat tipe pencarian informasi, yaitu perhatian pasif (passive attention), pencarian pasif (passive search), pencarian aktif (active search), dan pencarian berlanjut (ongoing search) (Wilson, 1999). Pertama, perhatian pasif terjadi saat seseorang tidak bermaksud mencari informasi, tetapi mendapatkan informasi. Kedua, pencarian pasif adalah saat seseorang mencari suatu informasi namun menemukan informasi yang lain yang kebetulan relevan dengan dirinya. Ketiga, pencarian aktif adalah saat seseorang secara aktif mencari informasi. Keempat, pencarian berlanjut merupakan pencarian informasi yang melakukan kelanjutan dari pencarian aktif guna memperdalam perspektif, gagasan, dan nilai seseorang.

Pada tahapan terakhir, perilaku pencarian informasi akan dilanjutkan dengan pengolahan informasi dan digunakan yang menjadi bagian penting dari feedback loop, jika kebutuhan informasi dipenuhi atau terpuaskan (Wilson, 1999). Istilah pengolahan dan penggunaan informasi menjelaskan perilaku informasi pengguna setelah mereka mendapatkan informasi dari berbagai sumber melalui mekanisme pencarian informasi yang berbeda-beda (Al-Suqri \& Al-Aufi, 2015).

Dalam konteks studi ini, fenomena hoaks yang semakin merebak di masyarakat memunculkan banyak penelitian mengenai hal tersebut. Penelitian hoaks muncul dari berbagai kajian ilmu dengan mengambil objek studi yang beragam. Bagian ini akan memaparkan sejumlah penelitian dengan tema hoaks dan media sosial untuk menunjukkan kebaruan penelitian ini.

Rahadi (2017) melakukan penelitian tentang perilaku pengguna dan informasi hoaks di media sosial pada 122 orang di lingkungan civitas akademik Universitas Presiden yang dipilih secara acak dari beberapa profesi. Penelitian Rahadi (2017) bertujuan untuk menganalisis perilaku informasi di media sosial dan persepsi mereka tentang dampak penyebaran hoaks, alasan penyebaran hoaks, dan cara menghambat hoaks. Penelitian Rahadi (2017) memiliki kemiripan dengan penelitian ini, namun pendekatan penelitian dan objek penelitiannya berbeda. Penelitian Rahadi (2017) menggunakan pendekatan kuantitatif dengan metode survei dan objeknya pada civitas akademika, sedangkan penelitian ini dilakukan dengan pendekatan kualitatif dengan metode focus groups discussion dan objeknya pada mahasiswa. Selanjutnya, penelitian Afifah, Muhlis, and Fatoni (2019) mendeskripsikan strategi dakwah serta metode yang digunakan santri dalam 
menyikapi berita di media sosial untuk menghindari hoaks. Objek pada penelitian ini berbeda dengan objek pada penelitian sebelumnya, objek pada penelitian ini adalah mahasiswa sedangkan objek penelitian Afifah et al. (2019) adalah santri.

Penelitian dengan objek mahasiswa sudah dilakukan sebelumnya. Pertama, penelitian Mahardika (2017) menjelaskan tentang perilaku mahasiswa Universitas Muhammadiyah Malang dalam menyikapi pemberitaan hoaks terkait isu corporate nasional di Facebook. Meski mengambil objek yang sama yakni mahasiswa, penelitian ini berbeda dengan penelitian Mahardika (2017). Penelitian Mahardika (2017) berfokus pada hoaks terkait isu corporate nasional di Facebook saja, sedangkan penelitian ini melihat perilaku mahasiswa dalam menyikapi hoaks secara umum, tidak spesifik pada satu isu dan tidak terbatas di Facebook saja.

Kedua, Fatkhurahman (2018) meneliti pada 79 mahasiswa di Fakultas Ekonomi Universitas Lancang Kuning. Fatkhurahman (2018) mengukur kemampuan menilai berita hoaks dari lima indikator yang meliputi kemampuan menilai judul, situs, konten, foto dan sumber palsu. Hasil penelitiannya menunjukkan bahwa kemampuan mahasiswa dalam kategori sedang Fatkhurahman (2018). Kemampuan tertinggi terletak pada kemampuan mengenali konten dan judul palsu, sedangkan kemampuan terendah ditemukan pada kemampuan mengidentifikasi sumber dan foto palsu. Penelitian Fatkhurahman (2018) berbeda dengan penelitian ini pada metode penelitian. Penelitian Fatkhurahman (2018) menggunakan pendekatan kuantitatif dengan survei sedangkan penelitian ini menggunakan pendekatan kualitatif dengan metode focus group discussion. Subjek penelitian Fatkhurahman (2018) terbatas dalam kemampuan menilai berita hoaks di media sosial dalam upaya pengembangan jiwa kewirausahaan, sementara penelitian ini melihat perilaku informasi mahasiswa terhadap hoaks di media sosial.

Ketiga, penelitian mengenai kemampuan dalam identifikasi berita hoaks juga dilakukan oleh Suyanto et al. (2018) meneliti tentang persepsi mahasiswa terhadap penyebaran berita bohong di media sosial pada mahasiswa Fakultas Ilmu Sosial dan Hukum Universitas Negeri Surabaya. Penelitian Suyanto et al. (2018) berbeda dengan penelitian ini karena penelitian Suyanto et al. (2018) menggunakan pendekatan kuantitatif dengan metode survei dan fokus pada level kognitif yaitu persepsi mahasiswa. Walaupun indikator persepsi mahasiswa juga melibatkan indikator afeksi seperti marah atau tidak suka dengan berita hoaks dan indikator konasi seperti cross check berita dari media sosial dan mengingatkan orang lain akan bahaya berita hoaks.

Keempat, penelitian Fitriana (2019) meneliti tentang persepsi dalam menilai berita hoaks pada mahasiswa Universitas Lampung. Dengan menggunakan model S-O-R (stimulus, organism, response), Fitriana (2019) meneliti delapan orang gubernur dan wakil gubernur BEM fakultas di Universitas Lampung dan menemukan 
bahwa informan mengenali berita hoaks yang diberikan peneliti, selektif dalam membaca berita dan tidak ikut meneruskan berita hoaks. Penelitian Fitriana (2019) berbeda dengan penelitian ini karena ia memfokuskan pada berita hoaks terkait grup media sosial LGBT di Universitas Lampung dan berita hoaks penistaan agama oleh Ahok. Meskipun meneliti persepsi, namun hasil penelitian Fitriana (2019) juga mengidentifikasi perilaku informasi dalam pemilihan sumber berita dan penyebaran berita.

Kelima, penelitian Anggraini (2016) mendeskripsikan perilaku penyebaran hoaks pada mahasiswa pascasarjana Universitas Gadjah Mada di grup WhatsApp. Penelitian Anggraini (2016) berbeda dengan penelitian ini pada subjek penelitian. Penelitian Anggraini (2016) meneliti pada perilaku penyebaran hoaks di grup WhatsApp, sementara penelitian ini melihat perilaku informasi yang tidak terbatas pada penyebaran hoaks saja, tetapi juga verifikasi informasi di media sosial secara umum.

Perbedaan mendasar studi ini dengan studi sebelumnya adalah penggunaan teori. Penelitian sebelumnya (Afifah et al., 2019; Fatkhurahman, 2018; Rahadi, 2017; Suyanto et al., 2018) tidak mengacu pada satu teori atau model teoritis tertentu. Ketiadaan teori dalam membahas perilaku informasi menyebabkan hasil penelitian bersifat deskriptif dan tidak analitik sehingga kurang kontribusi terhadap pengembangan literatur akademik. Sementara studi ini menggunakan model pencarian informasi oleh Wilson (1996) sebagai landasan teoritis yang mana teori ini sangat relevan untuk menjelaskan tentang perilaku informasi karena menekankan pada pencarian informasi melalui berbagai sumber baik sumber interpersonal maupun media. Penelitian pada kelompok mahasiswa sebelumnya yang menggunakan model pencarian informasi oleh Wilson tahun 1996 berfokus untuk menjelaskan perilaku informasi pada mahasiswa. Sebagai contoh, penelitian tentang perilaku pencarian informasi reproduksi seksual pada mahasiswa Universitas Sriwijaya (Meilinda et al., 2018) dan penelitian tentang perilaku informasi di perpustakaan pada mahasiswa pascasarjana UIN Sunan Kalijaga (Bidayasari, 2018). Sementara penelitian ini menggunakan model informasi Wilson tahun 1996 untuk menjelaskan bagaimana perilaku informasi mahasiswa dalam menyikapi hoaks di media sosial. Dalam era disrupsi digital, mahasiswa sebagai pengguna aktif media sosial sering sekali terpapar dengan hoaks sehingga cara mahasiswa memverifikasi informasi yang diterima hingga menyebarkan informasi dapat dilihat sebagai suatu perilaku informasi.

Penelitian ini bertujuan menjelaskan perilaku informasi mahasiswa dalam menyikapi hoaks di media sosial. Penelitian ini secara spesifik melihat sikap terhadap informasi di media sosial, verifikasi informasi serta perilaku penyebaran informasi di media sosial. Secara akademis, studi ini memberikan analisis yang berbeda dengan menggunakan kerangka berpikir model perilaku informasi oleh Wilson tahun 1996 yang belum pernah digunakan dalam studi terdahulu terkait 
hoaks di media sosial. Hasil penelitian ini diharapkan mampu untuk meninjau relevansi model perilaku informasi oleh Wilson di era media sosial. Hasil penelitian juga diharapkan mampu berkontribusi secara praktis terhadap pengembangan model literasi media untuk menangkal hoaks di kalangan mahasiswa.

Penelitian ini menggunakan pendekatan kualitatif dan dilakukan pada mahasiswa Universitas Syiah Kuala. Universitas Syiah Kuala merupakan universitas terbesar di Aceh dengan akreditasi A sehingga mahasiswanya dianggap cukup representatif untuk mewakili seluruh mahasiswa di Provinsi Aceh. Studi sebelumnya mengindikasikan bahwa mahasiswa di Banda Aceh merupakan pengguna media sosial yang aktif (Syam \& Nurrahmi, 2020).

Teknik pengumpulan data pada penelitian ini adalah Focus Group Discussion (FGD). Penggunaan teknik FGD dimaksudkan untuk mendapatkan data yang lebih mendetail tentang perilaku informasi mahasiswa dalam menghadapi hoaks di media sosial. FGD dilakukan terpisah pada dua kelompok mahasiswa, satu kelompok mahasiswa dan satu kelompok mahasiswi Universitas Syiah Kuala pada tanggal 22 Agustus 2019. Pemisahan kelompok berdasarkan jenis kelamin bertujuan untuk meminimalisir tekanan psikologis pada informan karena adanya perbedaan jenis kelamin dalam kelompok FGD.

Satu kelompok FGD terdiri dari tujuh orang mahasiswa yang dipilih dengan teknik purposif dengan tetap memperhatikan prinsip keberagaman. Masingmasing informan diberikan nomor 1 hingga 7 diikuti kode A untuk laki-laki dan B untuk perempuan. Kriteria informan adalah mahasiswa S-1 di Universitas Syiah Kuala yang memiliki lebih dari dua akun media sosial dan merupakan pengguna media sosial aktif. Informan dalam satu kelompok FGD akan terdiri dari berbagai latar belakang SMA dan fakultas atau program studi (jurusan). Setiap kelompok FGD akan dipandu oleh satu orang moderator.

Data yang diperoleh dari FGD akan dibuat dalam transkrip dan dianalisis dengan menggunakan teknik analisis data kualitatif model Miles, Huberman, and Saldaña (2014) yang terdiri dari data collection, condensation dan presentation. Data kemudian diuji keabsahannya dengan menggunakan teknik triangulasi, yaitu mencocokkan data dari hasil informan yang satu dengan informan yang lain dalam kelompok FGD (Moleong, 2007). Apabila didapatkan tingkat kesesuaian data antara satu informan dengan informan yang lain, maka data itu dianggap sah dan dapat digunakan sebagai hasil penelitian.

\section{HASIL DAN PEMBAHASAN}

\section{Sikap terhadap Informasi di Media Sosial}

Menurut informan, mereka tidak mudah mempercayai informasi yang beredar di media sosial. Mereka sering curiga apakah berita yang mereka terima hoaks atau bukan terutama saat Pemilihan Presiden 2019 lalu. 
Sering curiga, karena waktu Pilpres kemarin, beredar video tentang yang pencoblosan, logikanya kalau yang kerja pendukung 01, tapi kenapa berani gitu sementara itu masih ada yang jaga, kan nggak mungkin senekat itu untuk ambil video, karena misalnya kita udah terikat ni sama 01 misalnya, pasti itu udah kan udah ada kunci supaya kita menjaga kerahasiaan. kalau misalnya itupun, kan langsung beredar tu warnanya keliatan. jadi kan orang tau itu sebenarnya siapa, kan nggak semudah itu untuk dapatin video yang cobloscoblos itu (Informan 1B, 22 Agustus 2019).

Lebih lanjut, beberapa informan mengaku tidak serta merta mempercayai informasi di media sosial, meskipun hal itu sejalan dengan pilihan politiknya. Salah satunya Informan 3B yang mengaku sering mencurigai berita yang negatif tentang paslon 01 meskipun ia mendukung paslon 02 .

Kalau saya pribadi, mempercayai informasi di media sosial dengan pendapat saya, itu nggak selalu juga. Kayak pemilu kemarin, saya kebetulan di kaum 02, namun sering kali berita yang menjelekkan 01 berlebihan. Saya berpikir juga ini pasti ada kecurangan, tapi yang nggak gitu juga, menjelekkannya itu kayak keterlaluan. Jadinya saya nggak percaya juga gitu (Informan 3B, 22 Agustus 2019)

Berdasarkan hasil FGD tersebut, diketahui bahwa mahasiswa sadar bahwa informasi yang mereka beredar di media sosial belum tentu kebenarannya. Mereka menyadari banyak bahwa hoaks beredar di media sosial. Temuan ini senada dengan studi Sulthan and Istiyanto (2019) yang menemukan bahwa mahasiswa kritis terhadap media sosial dan mereka mengetahui adanya dampak negatif dari penggunaan media sosial, salah satunya hoaks.

\section{Verifikasi Informasi di Media Sosial}

Kebanyakan informan mengaku sulit membedakan informasi hoaks atau bukan di media sosial. Mereka mencontohkan banyaknya berita hoaks yang beredar selama Pilpres 2019 di media sosial yang menyebabkan mereka kebingungan untuk menilai kredibilitas informasi yang mereka terima. Banyak sekali berita negatif yang beredar dari kedua kubu politik saat itu sehingga membuat informasi yang beredar di media sosial simpang siur.

Ya emang kalau itu fenomena sekarang kan pak, kita nggak tahu lagi mana yang benar mana yang salah, jadi informasi yang disampaikan melalui media sosial, seperti di yang tersebar Facebook contohnya, rata-rata informasinya itu kita nggak tahu kebenarannya itu, emang benar seperti itu atau memang yang seperti apa. Contohnya kemarin pada masa-masa kampanye atau pilpres, itu banyak sekali, kita nggak tahu kepada siapa bisa kita pegang kebenarannya, karena sepertinya kedua belah pihak ini saling menjelekkan, 
disitulah kita jadinya nggak mau lagi percaya kepada media sosial (Informan 1A, 22 Agustus 2019).

Secara spesifik, Informan 2B menyebutkan bahwa berita politik merupakan berita yang paling sulit ia verifikasi kebenarannya. Berbeda halnya dengan berita viral yang relatif mudah untuk diklarifikasi.

Kalau saya pak, kalau di politik saya sering bingung, saya susah bedain "ini bener nggak?", tapi kalau berita-berita yang lagi viral itu, saya nggak bingung kali lah, karena saya bisa cross check atau diskusi dengan teman-teman. Tapi, kalau politik saya kurang, bingung gitu, nggak tau kemana cross check-nya (Informan 2B, 22 Agustus 2019).

Temuan yang memperlihatkan bahwa mahasiswa kesulitan untuk mengenali informasi hoaks bertentangan dengan penelitian sebelumnya yang menunjukkan bahwa mahasiswa mengaku memiliki strategi untuk menanggulangi dampak negatif tersebut (Sulthan \& Istiyanto, 2019). Studi ini menunjukkan bahwa mahasiswa memiliki keterbatasan dalam menanggulangi informasi hoaks di media sosial. Hal ini disebabkan oleh rendahnya keyakinan akan kemampuan diri sendiri dalam memverifikasi informasi. Dengan kata lain, self efficacy mereka dalam menilai informasi sebagai hoaks atau bukan, rendah. Hal ini yang kemudian menyebabkan informan tidak yakin apakah informasi yang mereka terima dan sebarkan hoaks atau bukan. Padahal dalam model perilaku informasi oleh Wilson (1996), self-efficacy merupakan activating mechanism dalam pencarian informasi. Self-efficacy yang rendah menyebabkan mereka enggan untuk melakukan pencarian informasi (Al-Suqri \& Al-Aufi, 2015). Studi Khan and Idris (2019) menekankan pentingnya self-efficacy dalam mengenali misinformasi online.

Penelitian ini menunjukkan bahwa mahasiswa mampu melakukan perbandingan informasi untuk memverifikasi informasi yang diterimanya. Informan mengaku membutuhkan waktu untuk memverifikasi kebenaran informasi yang beredar di media sosial. Biasanya mereka mengecek kebenaran suatu informasi dengan membandingkan informasi tersebut di beberapa media. Ada yang membandingkan informasi dengan menelusuri informasi tersebut di media sosial lain, namun ada juga yang mengecek dari media mainstream seperti surat kabar dan televisi. Rata-rata informan mengaku memverifikasi informasi dengan cara membandingkan informasi yang diterimanya di salah satu media sosial dengan media lain.

Misal suatu informasi itu viral, baru saya cek kembali informasi tersebut, misalnya terus nanti ada sama kawan-kawan duduk kemudian cerita ada informasi-informasi apa gitu, saya nggak bilang langsung juga itu tidak benar, tetapi saya cek dulu kebenarannya, saya membandingkan dengan berbagai media, pertama saya lihat dari TV, kalau sudah viral di TV berarti 
itu ya sudah betul, terus yang kedua kalau ada di koran, kalau di Instagram saya mengikuti Koran yang memiliki akun Instagram, kemudian akhirnya saya meng-compare informasi itu (Informan 2A, 22 Agustus 2019).

Selain menggunakan media, ada juga yang bertanya kepada orang lain untuk memverifikasi kebenaran informasi yang diterimanya.

Kalau saya pribadi, tidak 100\% mempercayai informasi yang beredar di media sosial, seperti yang saya bilang tadi saya meng-cross check dulu bagaimana kebenarannya, kecuali itu memang terjadi di lingkungan saya dan saya akan menanyakan pendapat dari mulut ke mulut, seperti kepada temanteman saya (Informan 2A, 22 Agustus 2019).

Informan 1A mencontohkan informasi yang tersebar di media sosial mengenai tiket pesawat gratis, dikarenakan informasi itu dibutuhkan dan ada kedekatan dengan informan, maka informan akan mencari kebenaran informasi tersebut dengan membaca dari sumber-sumber lain termasuk menanyakan langsung ke bandara.

Kalau saya tergantung beritanya, jika beritanya membuat saya tertarik dan memiliki kedekatan maka saya kritisi. Contoh seperti ada informasi tiket pesawat gratis kemudian beritanya di sebar-sebar, jadi pas disebarkan itu saya kritisi, "kenapa ni bisa gratis?", jadi informasi yang dekat saya kritisi, jadi kebetulan saya mempunyai kenalan yang bekerja di Bandara, jadi saya tanya sama beliau, dan itu memang hoax (Informan 1A, 22 Agustus 2019).

Studi ini juga memperlihatkan bahwa verifikasi informasi yang dilakukan mahasiswa tidak hanya terbatas pada sumber-sumber di dunia maya, seperti media online namun juga sumber informasi offline seperti teman. Hal ini senada dengan pernyataan Wilson (2000) bahwa ketika mencari informasi saat pencarian, seseorang akan terlibat dengan sistem informasi manual dan sistem berbasis komputer. Meskipun mahasiswa mendapatkan informasinya secara online baik dari media sosial maupun akun media sosial yang dimiliki oleh media massa, verifikasi informasi tetap melibatkan komunikasi interpersonal dengan orang lain, dalam konteks ini yang paling dominan adalah teman (peer groups).

Temuan lain memperlihatkan bahwa sikap kritis mahasiswa terhadap informasi tidak dibarengi oleh perilaku kritis. Berdasarkan pengakuan informan, ada mahasiswa yang tidak melakukan verifikasi informasi dari berbagai sumber. Mereka hanya bergantung pada satu sumber saja untuk verifikasi informasi. Mereka menyadari bahwa idealnya mereka membandingkan informasi yang diterimanya dari berbagai media. Namun rasa bosan hingga kurangnya waktu menjadi alasan untuk tidak melakukan hal tersebut. Sehingga mereka hanya membaca informasi dari satu media tanpa membandingkan lagi. 
Itu inginnya kita pak, maksudnya ingin membandingkan berita yang sama terhadap banyak media, tapi bagaimana mahasiswa sekarang itu dalam menggunakan waktu, waktu ini kan cenderung kita nggak punya banyak waktu, kita merasa bosan untuk membandingkan satu berita terhadap banyak media, jadi kita membaca terhadap banyak berita itu lebih cenderung membuat kita dalam membandingkan berita itu kurang pak. Jadi, lebih cenderung baca satu berita di satu media tanpa membandingkan lagi pak, karena merasa bosan pak (Informan 3A, 22 Agustus 2019).

Fenomena ini disebut dengan lack of thinking (Pennycook \& Rand, 2018, 2019). Keengganan mahasiswa untuk melakukan verifikasi atas informasi yang mereka terima akan membuat mereka mudah mempercayai hoaks

Lebih lanjut, mayoritas informan mengakui bahwa tidak semua informasi yang mereka terima akan dicek kebenarannya. Mereka hanya melakukan verifikasi informasi yang sesuai dengan kebutuhan dan preferensi mereka. Hal ini sesuai dengan hasil penelitian Adiarsi, Stellarosa, and Silaban (2015). Ketika mahasiswa menemukan informasi yang menarik minat mereka, mereka akan termotivasi untuk memverifikasi informasi tersebut.

Kalau misalnya informasinya sesuai dengan kebutuhan, pasti menganalisisnya lebih jauh, terus lebih intens meng-cross check nya dari berbagai sumber (Informan 7B, 22 Agustus 2019).

Akan tetapi, apabila informasi itu tidak dibutuhkan atau tidak ada hubungannya dengan diri informan, biasanya informasi tersebut akan diabaikan. Mereka tidak akan menganalisis informasi tersebut lebih lanjut.

Tergantung dari beritanya, kalau beritanya menarik saya akan mencari dari berbagai sumber, kalau nggak, ya udah gitu (Informan 2B, 22 Agustus 2019).

Di samping itu, hasil penelitian ini juga menunjukkan bahwa mahasiswa cenderung tidak melakukan verifikasi terhadap informasi yang konsisten dengan preferensi politik maupun yang disampaikan oleh orang yang dikaguminya. Informan menyebutkan bahwa, masih banyak mahasiswa yang mempercayai bahkan segala informasi yang disampaikan oleh media sosial, apalagi jika informasi tersebut sesuai dengan pilihan politiknya. Misalnya saat Pilpres 2019 lalu, semua informasi yang disampaikan untuk menjelekkan capres dan cawapres lain dan menguntungkan capres dan cawapres pilihannya, mereka akan mempercayainya, tidak peduli informasi tersebut hoaks atau tidak. Hasil ini berlawanan dengan hasil penelitian Pennycook and Rand (2019) yang menyebutkan bahwa penerimaan dan penolakan terhadap hoaks tidak dipengaruhi oleh preferensi politik. Selain itu, berdasarkan pengakuan salah satu informan, ia sering mendapati para fans dari public figure tertentu akan mempercayai informasi positif mengenai public figure 
tersebut maupun yang disampaikan oleh orang tersebut, meskipun informasi tersebut hoaks. Jika ditinjau dengan model perilaku informasi, temuan yang memperlihatkan adanya indikasi seseorang tidak melakukan verifikasi informasi karena informasi yang disebarkan sesuai dengan pilihan politiknya merupakan faktor psikologis (Wilson, 1999). Fanatisme dan preferensi politik menjadi intervening variable dalam model Wilson ini karena hal tersebut menjadi faktor yang mendorong seseorang untuk melakukan atau tidak melakukan pengecekan informasi yang diterimanya. Saat informasi tersebut linear dengan preferensi politiknya, ia merasa tidak perlu melakukan pengecekan informasi.

\section{Sharing Behaviour}

Perilaku penyebaran informasi menurut model ini termasuk perilaku informasi. Perilaku informasi dalam model perilaku informasi ini meliputi tidak hanya identifikasi kebutuhan dan pencarian informasi, tetapi juga penggunaan dan transfer informasi (Wilson, 1999). Dengan demikian, penyebaran informasi di media sosial yang dilakukan oleh mahasiswa di media sosial termasuk dalam perilaku informasi.

Menurut sebagian besar informan, ketika sebuah informasi didapatkan di media sosial, mereka cenderung tidak meneruskan informasi yang mereka terima. Jika ingin menyebarkan informasi, mereka akan mencari tahu terlebih dahulu kebenaran informasi tersebut dari sumber-sumber yang lain. Jika sudah jelas kebenarannya baru disebarkan ke orang lain.

Kalau saya, saya tidak suka share kayak berita-berita gitu, kalau berita-berita gitu kan harus di saring dulu baru di share, harus betul-betul (Informan 7A, 22 Agustus 2019).

Terkait penyebaran informasi, penelitian ini menemukan bahwa beberapa informan mengaku tidak pernah menyebarkan hoaks. Sebagian besar informan mengatakan bahwa banyak teman sesama mahasiswa yang sering membagi informasi tanpa cross check terlebih dahulu. Padahal jika dianalisis lebih lanjut, mereka sendiri mengaku tidak yakin apakah informasi yang mereka sebarkan hoaks atau bukan. Temuan ini sejalan dengan studi Jang and Kim (2018) yang menemukan bahwa ada fenomena third-party effect dalam fenomena hoaks di mana seseorang akan merasa orang lain yang termakan hoaks, sedangkan dirinya tidak.

Tetapi, sekarang masih banyak yang meng-share walaupun berita tersebut masih simpang siur. Contohnya di grup sosial media saya, itu di post semua tanpa disaring terlebih dahulu. Kawan-kawan saya masih banyak yang mengshare informasi atau berita yang masih simpang siur ataupun belum tentu berita itu benar (Informan 1B, 22 Agustus 2019).

Studi ini juga menemukan bahwa masih terdapat penyebaran informasi baik 
kepada individu maupun ke dalam grup di media sosial sebelum di cross check. Penyebaran informasi tanpa verifikasi diakui informan terjadi saat suatu informasi sesuai dengan kebutuhan mereka sebagai mahasiswa. Mereka mengaku sering meneruskan informasi yang dianggap bermanfaat untuk kalangan mahasiswa seperti informasi beasiswa tanpa melakukan verifikasi terlebih dahulu. Oleh karena itu, besar kemungkinan bahwa mereka juga menyebarkan informasi hoaks di media sosial. Meski mengaku sering melakukan konfirmasi kebenaran informasi sebelum meneruskan ke orang lain, mayoritas informan mengatakan kadang mereka juga menyebarkan informasi yang mereka rasa bermanfaat untuk diketahui orang lain tanpa memverifikasinya terlebih dahulu. Mereka mengakui bahwa mungkin saja informasi yang mereka teruskan itu hoaks. Mereka baru memverifikasi informasi tersebut setelah mendapatkan komentar yang mempertanyakan kebenaran informasi yang mereka teruskan.

Cuma kalau tentang kegiatan di lingkungan mahasiswa gitu, share-share aja gitu pak, karena itu bermanfaat (Informan 4B, 22 Agustus 2019).

Hal ini menunjukkan paradoks perilaku pada kelompok mahasiswa di mana mereka memiliki kecenderungan reaktif dengan meneruskan informasi yang mereka baca atau terima di media sosial tanpa verifikasi saat informasi tersebut relevan dengan kebutuhan mereka, namun bersikap kritis dengan melakukan cross check terhadap informasi lainnya. Temuan ini sejalan dengan temuan Rahadi (2017) bahwa perilaku share sebelum cross check merupakan perilaku yang paling sering dilakukan pada saat menerima informasi di media sosial.

Di sini informan merasa bahwa informasi seperti beasiswa, tiket murah, kuota internet gratis, bermanfaat, sehingga mendorong mereka untuk berbagi informasi tersebut yang belakangan mereka ketahui sebagai hoaks. Hasil penelitian ini berbeda dengan hasil penelitian Anggraini (2016) yang menunjukkan bahwa penyebaran informasi hoaks salah satunya dikarenakan kurangnya rasa tanggung jawab dalam berinteraksi. Jika dilihat dari perspektif membagikan informasi yang belum diketahui kebenarannya, maka dapat dilihat sebagai perilaku yang tidak bertanggung jawab (irresponsible behaviour). Namun apabila ditinjau dari motif, maka motif penyebaran informasi yang dirasa bermanfaat dapat diinterpretasikan sebagai motif yang didasari oleh tanggung jawab dalam berinteraksi berupa keinginan untuk berkontribusi positif dalam interaksi dengan orang lain. Asumsi lainnya, perilaku tersebut didasari oleh faktor emosional, karena informasi tersebut relevan dengan kebutuhan mereka sehingga mereka mudah larut dan terbawa emosi dan akhirnya turut menyebarkan informasi tersebut (Fatkhurahman, 2018). Ringkasan hasil penelitian dapat dilihat pada Tabel 1 di bawah ini: 
Tabel 1. Ringkasan Hasil Penelitian

\begin{tabular}{|c|c|c|}
\hline No. & Dimensi & Hasil \\
\hline 1 & Sikap terhadap informasi & $\begin{array}{l}\text { Kritis terhadap informasi yang } \\
\text { diterimanya di media sosial }\end{array}$ \\
\hline \multirow[t]{4}{*}{2} & Verifikasi informasi & $\begin{array}{l}\text { Terkadang sulit membedakan informasi } \\
\text { hoaks dan bukan }\end{array}$ \\
\hline & & $\begin{array}{l}\text { Mampu melakukan verifikasi nformasi } \\
\text { Menggunakan berbagai sumber } \\
\text { informasi }\end{array}$ \\
\hline & & $\begin{array}{l}\text { Ada yang malas melakukan verifikasi } \\
\text { sehingga bergantung pada satu sumber } \\
\text { Hanya konfirmasi informasi yang sesuai } \\
\text { dengan minat dan kebutuhan }\end{array}$ \\
\hline & & $\begin{array}{l}\text { Tidak verifikasi informasi yang } \\
\text { berkaitan dengan pilihan politik atau } \\
\text { orang yang dikaguminya. }\end{array}$ \\
\hline \multirow[t]{2}{*}{3} & Perilaku penyebaran & $\begin{array}{l}\text { Menyebarkan informasi yang terlah } \\
\text { terverifikasi }\end{array}$ \\
\hline & & $\begin{array}{l}\text { Terkadang menyebarkan informasi yang } \\
\text { belum terverifikasi karena informasi } \\
\text { tersebut dianggap bermanfaat }\end{array}$ \\
\hline
\end{tabular}

Sumber: Hasil analisis data

Jika dianalisis dengan model perilaku informasi dari Wilson (1996), dapat dikatakan keempat tipe perilaku pencarian informasi ditemukan dalam studi ini. Pertama, tipe perilaku pencarian informasi yang paling banyak terjadi pada mahasiswa adalah perhatian pasif. Mahasiswa yang memiliki banyak akun media sosial dan sering mengakses media sosial akan mendapatkan terpaan informasi yang begitu besar. Hal ini dapat dikarenakan informasi adalah komoditas utama dari media sosial (Nasrullah, 2015). Kedua, implikasi lain dari terpaan informasi di media sosial adalah munculnya perilaku pencarian pasif. Berdasarkan hasil FGD, diketahui bahwa beberapa mahasiswa memang menjadikan media sosial tempat mencari informasi, namun tidak spesifik pada informasi tertentu. Dalam proses pencarian informasi, mereka akan menemukan sejumlah informasi yang menarik perhatian mereka. Ketiga, dari hasil analisis juga terlihat bahwa ada sekelompok mahasiswa yang melakukan pencarian aktif, namun hanya pada informasi yang memang sesuai dengan kebutuhan dan minat mereka. Keempat, informasi yang relevan dengan minat dan kebutuhan mereka sebagai mahasiswa, baik yang mereka dapatkan dari pencarian aktif maupun pencarian pasif, kemudian mendorong 
mereka untuk melakukan pencarian berlanjut. Dalam konteks ini, saat mahasiswa melakukan verifikasi informasi yang mereka terima dapat dikatakan bahwa mereka melakukan pencarian berlanjut. Verifikasi informasi yang mereka lakukan merupakan pencarian informasi yang lebih lanjut dalam rangka konfirmasi kebenaran informasi yang mereka terima di media sosial.

\section{PENUTUP}

Merujuk pada hasil penelitian, dapat disimpulkan bahwa perilaku mahasiswa terhadap informasi masih belum mumpuni untuk menangkal hoaks di media sosial. Secara umum, penggunaan media sosial mereka diikuti oleh sikap yang relatif kritis terhadap konten dengan tidak segera mempercayai informasi di media sosial.

Pada aspek verifikasi informasi, studi ini menemukan bahwa mahasiswa masih kesulitan untuk membedakan antara hoaks atau bukan, meski mereka menunjukkan keinginan untuk memverifikasi informasi yang diterima. Mayoritas mahasiswa menggunakan berbagai sumber mulai dari sumber interpersonal, media massa, media sosial dan media online untuk mengkonfirmasi apakah informasi yang diterimanya hoaks atau bukan.

Mereka juga tidak konsisten melakukan verifikasi informasi. Ada yang hanya bergantung pada satu sumber dalam verifikasi informasi dikarenakan rasa jenuh dan malas. Selain itu, hanya informasi yang sesuai dengan minat dan kebutuhan mereka yang akan dicek kebenarannya. Masih banyak juga yang tidak melakukan konfirmasi informasi jika informasi itu sesuai dengan pilihan politik atau berkaitan dengan orang yang dikaguminya. Terkait perilaku penyebaran, mayoritas informan mengaku hanya menyebarkan informasi yang telah diverifikasi kebenarannya. Namun, sebahagian dari mereka cenderung untuk berbagi informasi yang belum diverifikasi karena informasi tersebut dirasa bermanfaat.

Studi ini menyarankan sebuah model literasi media sosial yang menitikberatkan pada cara identifikasi hoaks untuk meningkatkan self-efficacy mahasiswa dalam pencarian informasi dan mengeksplorasi konsekuensi hoaks untuk meminimalisir perilaku penyebaran hoaks di kalangan mahasiswa, khususnya di Aceh.

Untuk penelitian selanjutnya, peneliti menyarankan agar dilakukan studi untuk melihat sejauh mana kemampuan mahasiswa mengidentifikasi hoaks, kendala yang dihadapi mahasiswa untuk menilai suatu informasi hoaks atau bukan, serta motif penyebaran informasi di media sosial.

\section{DAFTAR PUSTAKA}

Adiarsi, G. R., Stellarosa, Y., \& Silaban, M. W. (2015). Literasi media internet di kalangan mahasiswa. Humaniora, 6(4), 470-482. 
Febri Nurrahmi \& Hamdani M. Syam

Afifah, L., Muhlis, A., \& Fatoni, U. (2019). Strategi Dakwah Santri dalam Menghadapi Berita Hoax di Media Sosial. Prophetica: Scientific and Research Journal of Islamic Communication and Broadcasting, 5(1), 97-114.

Al-Suqri, M. N., \& Al-Aufi, A. S. (2015). Information seeking behavior and technology adoption: Theories and trends: Information Science Reference.

Aminah, A., \& Sari, N. (2019). Dampak Hoax di Media Sosial Facebook Terhadap Pemilih Pemula. Jurnal Komunikasi Global, 8(1), 11. doi:10.24815/jkg.v8i1.13565

Anggraini, C. N. (2016). Literasi Media Baru dan Penyebaran Informasi Hoax. (Master). Universitas Gadjah Mada,

APJII. (2017). Penetrasi \& Perilaku Pengguna Internet Indonesia. Retrieved from https://web.kominfo.go.id/sites/default/files/Laporan \%20Survei\%20AP JII_2017_v1.3.pdf.

Bidayasari, S. (2018). Perilaku Penemuan Informasi Berdasarkan Teori Wilson di Perpustakaan Uin Sunan Kalijaga Pada Mahasiswa Pascasarjana Ilmu Perpustakaan dan Informasi. Nusantara-Journal of Information and Library Studies, 1(2), 113-128.

Fatkhurahman, F. (2018). Kemampuan Mahasiswa Tempatan Menilai Berita Palsu Atau "Hoax" Dalam Media Sosial Dalam Upaya Pengembangan Jiwa Kewirausahaan. Jurnal Benefita: Ekonomi Pembangunan, Manajemen Bisnis \& Akuntansi, 3(3), 417-426.

Faturrahman, M. (2016). Model-model perilaku pencarian informasi. JIPI Jurnal Ilmu Perpustakaan dan Informasi), 1(1), 74-91.

Fitriana, K. N. (2019). Persepsi Mahasiswa Universitas Lampung Dalam Menilai Berita Hoax. (Undergraduate). Universitas Lampung,

Garg, M. (2016). Information seeking behaviour models: A brief introduction. International Journal of Library and Information Studies, 6(1), 161-168.

Jang, S. M., \& Kim, J. K. (2018). Third person effects of fake news: Fake news regulation and media literacy interventions. Computers in Human Behavior, 80, 295-302.

KBBI Daring. (2019). Hoaks. Retrieved from https://kbbi.kemdikbud.go.id/entri/hoaks

Khan, M. L., \& Idris, I. K. (2019). Recognise misinformation and verify before sharing: a reasoned action and information literacy perspective. Behaviour \& Information Technology, 38(12), 1194-1212. doi:10.1080/0144929X.2019.1578828

Kominfo. (2019). Kominfo Jaring 771 Konten Hoax, Mayoritas Terkait Politik Retrieved from https://kominfo.go.id/content/detail/17071/kominfojaring-771-konten-hoax-mayoritas-terkait-politik/0/sorotan_media

Lazer, D. M. J., Baum, M. A., Benkler, Y., Berinsky, A. J., Greenhill, K. M., Menczer, F., . . Z Zittrain, J. L. (2018). The science of fake news. Science (New 
York, N.Y.), 359(6380), 1094. doi:10.1126/science.aao2998

Mahardika, Y. R. C. (2017). Perilaku Mahasiswa dalam Menyikapi Pemberitaan Hoax di Media Sosial Facebook (Studi pada Mahasiswa Ilmu Komunikasi Universitas Muhammadiyah Malang Angkatan 2013 yang Menerima Pemberitaan Hoax Terkait Isu Corporate Nasional). (Undergraduate). University of Muhammadiyah Malang,

Mastel. (2017). Infografi Hasil Survei Mastel Tentang Wabah Hoax Nasional. Retrieved from https://mastel.id/infografis-hasil-survey-mastel-tentangwabah-hoax-nasional/

Meilinda, N., Prabujaya, S. P., \& Murti, K. (2018). Pola Pencarian Informasi tentang Reproduksi Seksual Pada Mahasiswa Universitas Sriwijaya. Jurnal Riset Komunikasi, 1(1), 128-135. doi: https://doi.org/10.24329/jurkom.v1i1.19

Miles, M. B., Huberman, A. M., \& Saldaña, J. (2014). Qualitative data analysis: A methods sourcebook. Thousand Oaks, CA Sage.

Moleong, L. J. (2007). Metodologi penelitian kualitatif. Bandung PT Remaja Rosdakarya.

Nasrullah, R. (2015). Media Sosial: Perspektif Komunikasi, Budaya, dan Sosioteknologi. Bandung: Simbiosa Rekatama Media.

Pennycook, G., \& Rand, D. G. (2018). Who falls for fake news? The roles of bullshit receptivity, overclaiming, familiarity, and analytic thinking. Journal of personality, Forthcoming.

Pennycook, G., \& Rand, D. G. (2019). Lazy, not biased: Susceptibility to partisan fake news is better explained by lack of reasoning than by motivated reasoning. Cognition, 188, 39-50.

Rahadi, D. R. (2017). Perilaku Pengguna dan Informasi Hoax di Media Sosial. Jurnal Manajemen Dan Kewirausahaan, 5(1), 58-70. Retrieved from http://jurnal.unmer.ac.id/index.php/jmdk/article/view/1342

Siswoko, K. H. (2017). Kebijakan Pemerintah Menangkal Penyebaran Berita Palsu atau 'Hoax'. Jurnal Muara Ilmu Sosial, Humaniora, dan Seni, 1(1), 13-19.

Statista. (2020a). Countries with the highest number of internet users as of June 2019.

Retrieved

from https://www.statista.com/statistics /262966/number-of-internet-users-inselected-countries /

Statista. (2020b). Penetration of leading social networks in Indonesia as of 3rd quarter 2019. Retrieved from https://www.statista.com/statistics/284437/indonesia-social-networkpenetration/

Sulthan, M., \& Istiyanto, S. B. (2019). Model Literasi Media Sosial Bagi Mahasiswa. Jurnal ASPIKOM, 3(6), 1076-1092. doi:10.24329/aspikom.v3i6.280 
Febri Nurrahmi \& Hamdani M. Syam

Suyanto, T., Prasetyo, K., Isbandono, P., Zain, I. M., Purba, I. P., \& Gamaputra, G. (2018). Persepsi mahasiswa terhadap kemunculan berita bohong di media sosial. Jurnal Civics: Media Kajian Kewarganegaraan, 15(1), 52-61. doi:10.21831/jc.v15i1.17296

Syam, H. M., \& Nurrahmi, F. (2020). "I Don't Know If It Is Fake or Real News" How Little Indonesian University Students Understand Social Media Literacy. Jurnal Komunikasi: Malaysian Journal of Communication, 36(2), 92-105.

Wilson, T. D. (1999). Models in information behaviour research. Journal of documentation, 55(3), 249-270.

Wilson, T. D. (2000). Human information behavior. Informing science, 3(2), 49-56.

Wilson, T. D. (2007). Evolution in Information Behavior Modeling Wilson's Model. In K. Fisher, S. Erdelez, \& L. McKechnie (Eds.), Theories of information behavior (pp. 31-36). Medford, N: Information Today. 